\title{
sciendo
}

\section{Statistical analysis of investments in transport infrastructure, passenger numbers, and energy consumption by modes of transport in Romania}

\author{
Alexandru-Eugen STĂTESCU \\ Bucharest University of Economic Studies, Bucharest, Romania \\ alexandrustatescu@yahoo.com
}

\begin{abstract}
Economic and financial analysis is a method of knowing the mechanism of formation and modification of the economic phenomena by their decomposition into the component elements and by identifying the factors of influence. The object of decomposition by elements or factors may be a result (structural analysis), or a change in the result from a basis of comparison (causal analysis).

In the present paper I propose an analysis of the investments according to the number of passengers and the consumption of energy on national transport modes in Romania within a period of 15 years, respectively between 2000 and 2015. For this purpose the data that will be used was published by the National Institute of Statistics, namely three indicators: investments in transport infrastructure, the weight of each mode in passenger transport and the consumption of energy by modes of transport.

Energy consumption by modes of transport is the final energy consumption of transport activity by modes of transport, expressed in tones oil equivalent (toe). The quantities of energy used in international maritime and air transport and pipeline transport are not included. The main types of fuels used are the main fuels covered by petroleum products, electricity and small amounts of gas and biofuels.

The weight of each mode in passenger transport is defined as the percentage share of each mode of transport in total domestic passenger transport. The modes of transport considered are: a) cars, b) buses and coaches, and c) trains (metro and trams and light metro are excluded). Domestic passenger transport includes data referring only to national transport, irrespective of the nationality of the transport vehicle. The weight is calculated from the passenger-km indicator ( $p k m)$, defined as the transport of a passenger over one kilometer.

The investments in the transport infrastructure represent the construction works carried out for the development of the transport infrastructure.

In order to carry out the statistical analysis of the investments in the transport infrastructure, the number of passengers and the energy consumption in transport modes in Romania, multiple linear regression models and time series analysis will be used.
\end{abstract}

Keywords: Financial and economic analysis, Multiple linear regression, Time series, Adjustment function, ARIMA models

\section{Introduction}

Economic and financial analysis is a method of knowing the mechanism of formation and modification of the economic phenomena by their decomposition into the component elements and by identifying the factors of influence. The object of decomposition by elements or factors may be a result (structural analysis), or a change in the result from a basis of comparison (causal analysis).

The methods of qualitative analysis aim at studying the structure of the phenomena, 
the factors that determine them and the causal relations between factors and phenomena. Qualitative analysis precedes and determines the results of quantitative analysis and is used in the exercise of all management functions, conditioning, to a certain extent, the efficiency of the solutions adopted by the management.

The methods of quantitative analysis are intended to give purpose to causal links, to quantify the action of various factors, to hierarchize the factors in order of their importance, to establish the existing reserves and the extent to which they have been capitalized.

In the present paper I propose an analysis of the investments according to the number of passengers and the consumption of energy on national transport modes in Romania within a period of 15 years, respectively between 2000 and 2015. For this purpose the data that will be used was published by the National Institute of Statistics, namely three indicators: investments in transport infrastructure, the weight of each mode in passenger transport and the consumption of energy by modes of transport.

Energy consumption by modes of transport is the final energy consumption of transport activity by modes of transport, expressed in tones oil equivalent (toe). The quantities of energy used in international maritime and air transport and pipeline transport are not included. The main types of fuels used are the main fuels covered by petroleum products, electricity and small amounts of gas and biofuels.

The weight of each mode in passenger transport is defined as the percentage share of each mode of transport in total domestic passenger transport. The modes of transport considered are: a) cars, b) buses and coaches, and c) trains (metro and trams and light metro are excluded). Domestic passenger transport includes data referring only to national transport, irrespective of the nationality of the transport vehicle. The weight is calculated from the passenger-km indicator ( $\mathrm{pkm})$, defined as the transport of a passenger over one kilometer.

The investments in the transport infrastructure represent the construction works carried out for the development of the transport infrastructure.

In order to carry out the statistical analysis of the investments in the transport infrastructure, the number of passengers and the energy consumption in transport modes in Romania, multiple linear regression models and time series analysis will be used.

\section{Literature review}

Romania has a national transport system (infrastructure, means of transport, transport operators, etc.), which is largely in terms of both the functional structure and the services provided, at the level of the average standards of the conventional transport in Europe, able to cope with the current needs of domestic and international users.

Overall, the public transport infrastructure network (roads, railways, waterways, maritime and river ports, airports) ensures the connection of all the localities of the country to the national network and the international transport systems.

Since 1990, notable efforts have been made to increase the capacity of existing infrastructure and systems, and to ensure socially sustainable development and environmental protection, transport efficiency and safety, to respond adequately to future transport demand at national level.

The White Paper on Transport Policy (published in 1992) defined a series of policies and measures at EU and EU level to launch / run the process leading to a sustainable transport system to be reached in about 30 years. The initial policies contained in the White 
Paper on transport policy have focused on making transport modes more attractive and attractive to transport and environmental protection. In 2006, in line with the emergence of new issues (EU enlargement, globalization, rising oil prices, terrorist threats), the principles set out in the Lisbon Strategy - Lisbon 2000 (competitiveness, working conditions, environmental protection) Cardiff 1998 and the European Sustainable Development Strategy - Gothenburg 2001 (Climate Change, Energy Consumption) some principles have been revised and new targets have been set for Community transport policy in general and sustainable development in the subsidiary.

Passengers transported are passengers who make a journey using means of transport characteristic of a mode of transport and intended, by design, for the carriage of passengers. Rail transport includes passengers departing from national railway stations regardless of destination and passengers entering the country via border stations.

Passenger registered data in maritime transport refer to cruise passengers, including cruise passengers on entry excursions.

The passenger journey expresses the volume of passenger transport determined by the number of passengers transported and by the distance traveled by each passenger in road, rail and inland waterways. For rail transport, the distance taken into account for the passenger journey is the distance traveled on the national rail network.

National passenger transport is the transport of passengers between two localities located on national territory.

International passenger transport is the transport of passengers between different national territories, a locality being located on the national territory.

Local public passenger transport is the passenger transport operation carried out by a road transport vehicle as well as by the metro within the territorial administrative area of a locality, without exceeding its limits.

Energy consumption by modes of transport is the final energy consumption of transport activity by modes of transport, expressed in tonnes of oil equivalent (toe). The quantities of energy used in international maritime and air transport and pipeline transport are not included. The main types of fuels used are the main fuels covered by petroleum products, electricity and small amounts of gas and biofuels.

The investments in the transport infrastructure represent the construction works carried out for the development of the transport infrastructure.

In the present paper I propose an analysis of the investments according to the number of passengers and the consumption of energy on national transport modes in Romania within a period of 15 years, respectively between 2000 - 2015. For this purpose, the data will be used published by the National Institute of Statistics, namely three indicators: investments in transport infrastructure, the weight of each mode in passenger transport and the consumption of energy in modes of transport.

\section{The multifactorial regression model}

On the general form, a multifactorial explanatory model is defined by the following relation: $y=f\left(x_{j}\right)+u$, where: $y=$ endogenous variable, dependent or explained; $x_{j}=$ exogenous variables, independent or explanatory; $j=\overline{1, k}, k=$ the number of exogenous variables; $u=$ residual variable or random or error; $f\left(x_{j}\right)=$ regression function with which will be estimated (approximate) the variable values $y$, determined only by the influence $x_{j}$, 
considered essential, main, decisive, unless other factors influence of the phenomenon $y$, factors that are considered nonessential, insignificant explain the emergence and evolution in time and space of the phenomenon $y$, them being treated separately using the residual variable $u$. The econometric model should be construed as a formal expression of the method econometric investigation of an economic purpose:

$$
\text { The Reality }(y)=\text { The Theory }\left[f\left(x_{j}\right)\right]+\text { Random }(u)
$$

As a general and fundamental rule specifying an econometric model is based on economic theory. The economic phenomenon $y$ states based on the concepts, definitions and cause-effect relationships developed by it and accepted phenomenon $x_{j}$ as an essential factor, or reject and pass through random factors in the category random variable $u$. Package size of explanatory variables $x_{j}$ also depends on statistical data bank of those variables, the quantity and quality of them.

As in the case of the single factor model, the econometric identification consists of choosing a mathematical function to describe the relationship, of the relation between endogenous variable $y$ and its factors of influence, $x_{1}, x_{2}, \ldots, x_{j}, \ldots, x_{k}$. This choice is consistent with the statistical series (series of space or time of the variable $y$ and variables $x_{j}$ ) of these variables, taken from a database or constructed following statistical observations specially organized. Thus, if you have the following information:

\begin{tabular}{|c|c|c|c|c|}
\hline$x_{11}$ & $x_{21}$ & $\ldots$ & $x_{k 1}$ & $y_{1}$ \\
\hline$x_{12}$ & $x_{22}$ & $\ldots$ & $x_{k 2}$ & $y_{2}$ \\
\hline$x_{13}$ & $x_{23}$ & $\ldots$ & $x_{k 3}$ & $y_{13}$ \\
\hline$\cdot$ & & & & \\
$\cdot$ & & & & \\
. & & & & \\
\hline$x_{1 n}$ & $x_{2 n}$ & $\ldots$ & $x_{k n}$ & $y_{n}$ \\
\hline
\end{tabular}

where: $t=\overline{1, n}, n=$ the number of terms of statistical series; $j=\overline{1, k}, k=$ the number of exogenous variables. Identifying means that, based on experimental data, $y_{t}$ and $x_{j t}$, to find a mathematical function, $Y_{t}=f\left(x_{j t}\right)$, with which estimate the values of the variable $y$ only on the basis of values $x_{j t}$.

Unlike unifactorial model case where the process of graphic or algebraic calculations provided information for identifying relatively accurate regression function, in multifactor models this remains true only if it will work with two-dimensional series: $y_{t}, x_{1 t} ; y_{t}, x_{2 t} ; y_{t}, x_{j t} ; \ldots ; y_{t}, x_{k t}$. Another way of choosing the multifactorial regression function is using estimation, verification and comparison of different types of regression functions and ultimately decide - see coefficients of performance of a model multifactorial linear - that is the most powerful model in report with experimental data.

Typically, the economy, the main features are as multifactor regression:

- linear function: $Y_{t}=b_{0}+b_{1} x_{1 t}+b_{2} x_{2 t}+\ldots+b_{k} x_{k t}$

- Double logarithmic linear function: $Y_{t}=b_{0} \cdot x_{1 t}^{b_{1}} \cdot x_{2 t}^{b_{2}} \cdot \ldots \cdot x_{k t}^{b_{k}}$

- semi-log linear function: $Y_{t}=e^{b_{0}+b_{1} x_{1 t}+b_{2} x_{2 t}+\ldots+b_{k} x_{k t}}$

Note that, both the model specification stage and the stage of identifying, the solutions accepted:

- $x_{j}$ - the main factors that influence the phenomenon $y$; 
- $Y_{t}=f\left(x_{j t}\right)=b_{0}+b_{1} x_{1 t}+b_{2} x_{2 t}+\ldots+b_{k} x_{k t} ; j=\overline{1, k}, t=\overline{1, n}$ (Tudorel Andrei, Régis Bourbonais, 2008:112)

- dependency relationship, are nothing but simple hypotheses. The validation or rejection of them will be, in fact, the main objective of the verification stage econometric model.

Application of the L. S. R. M. (least square root method) in a multifactor model is based on several assumptions, namely:

I1: Variables $y, x_{1}, \ldots, x_{k}$ are not affected by errors of measurement.

I2: The random variable (residual) $U$ average is null $M\left(u_{1}\right)=M\left(u_{2}\right)=\ldots=M\left(u_{n}\right)=0$, and its dispersion $\sigma_{u}^{2}$ is constant and independent of exogenous variables $X_{j}$ - hypothesis homoscedasticitate.

I3: Residual variable values $U$ are independent, namely the phenomenon of autocorrelation of errors, $o v\left(u_{1}, u_{n}\right)=0, \forall t, t=\overline{1, n}$.

I4: The law of probability of the residual variable is the normal law of mean zero and standard deviation $\sigma_{u}$.

Outside these assumptions, which are the same in the case of a single factor model, there is a specific hypothesis of the multifactorial model, namely - I5: exogenous variables $X_{j}$ are independent of each other, resulting a system of linearly independent vectors. Otherwise the multicolinearity phenomenon occurs involving the impossibility of calculating inverse matrix $\left(X^{\prime} X\right)^{-1}$, and estimation parameters. (Isaic - Maniu, A 1999:172)

Estimation of model parameters is made after the identification step. Because the vast majority of econometric models can be linearized, a multifactorial model, in general, is as follows:

$y_{t}=b_{0} x_{0 t}+b_{1} x_{1 t}+b_{2} x_{2 t}+\ldots+b_{k} x_{k t}+u_{t} ; j=\overline{1, k}, t=\overline{1, n}, \quad n=$ the number of statistical series terms, and $k=$ the number of exogenous variables.

In the case of a multifactor model, the parameters can be estimated by several methods such as empirical points method, midpoint method, least squares method (L.S.M.), maximum fidelity method, etc. The empirical point method and the average point method are used in models where the least squares method is difficult to handle, requiring complicated calculations, typically for nonlinear functions (logistics function). The smallest square method is the most commonly used method.

In the case of a multifactor model, its application involves minimizing the function: $F(\widehat{B})=\min \sum_{t=1}^{n} u_{t}^{2}=\min U^{\prime} U=\min (Y-\hat{Y})^{2}=\min (Y-X \widehat{B})^{2}, \quad$ which implies calculating the derivative of the function in relation to the estimator $\widehat{B}$ and its cancellation:

$$
\frac{\partial F(\hat{B})}{\partial \hat{B}}=0 \rightarrow-2\left(X^{\prime} Y\right)+2\left(X^{\prime} X\right) \hat{B}=0 \rightarrow \hat{B}=\left(X^{\prime} X\right)^{-1}\left(X^{\prime} Y\right)
$$

Where $X=\left(\begin{array}{cccc}1 & x_{11} & \cdots & x_{1 k} \\ \vdots & \ddots & & \vdots \\ 1 & x_{n 1} & \cdots & x_{n k}\end{array}\right)$ represents the matrix of the exogenous variables $\left(x_{j}\right), j=$ $\overline{0, k}, Y=\left(\begin{array}{c}y_{1} \\ y_{2} \\ \ldots \\ y_{n}\end{array}\right)$ is the column vector of the endogenous variable $\left(y_{t}\right), t=\overline{1, n}, B=\left(\begin{array}{c}b_{1} \\ b_{2} \\ \ldots \\ b_{n}\end{array}\right)$ is the parameter column vector $\left(b_{j}\right), j=\overline{0, k}$, and $\hat{Y}, \hat{B}$ are the vectors estimators $Y, B$.(Tudorel, A., Stancu, S., Iacob, A. I., Tușa, E., 2008:95) 


\section{Time series. Stationarity. Statistical tests}

Chronological series is a form of orderly presentation of statistical data that reflects the level of manifestation of phenomena at a given time or period of time. In other words, the chronological series is a series of values of an economic or other indicator, observed over time, mirroring the process of changing and developing a statistical collectivity over successive periods of time.

The general form of a chronological series can be as follows:

where:

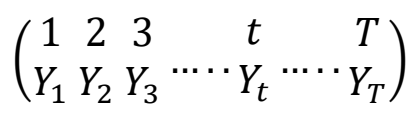

$t=$ time or time interval $(t=1, T)$;

$y t=$ the level (expressed by absolute or relative data) reached by the $Y$ phenomenon at time $t$. (Stancu, S. 2011:379)

The statistical description of the time series starts from the analysis of the factors causing their movement. Generally, the evolution of a phenomenon is generated by the action of some groups of factors:

- the essential factors with long-lasting action, which implies the trend of their evolution; the action of these factors being studied according to the time units for which the phenomenon analyzed was measured;

- seasonal factors, for periods of less than one year, which lead to deviations from the trend of the phenomenon imprinted by the essential factors;

- cyclical factors, with effects over periods of more than one year, which imply a oscillating evolution of the phenomenon in the case of long-time series;

- Random factors (random action), the action of which is compensated if the recorded data refers to a large number of periods of time.

Starting from the structure of the factors that determine the evolution of a phenomenon, the statistical description of the time series can be made using the following models:

1. Addition models

$$
y t=f(t)+s(t)+c(t)+u(t)
$$

2. Multiplicative models

$$
y t=f(t) \cdot s(t) \cdot c(t) \cdot u(t)
$$

where:

$f(t)=$ the trend component, the effect of the action of the key factors;

$s(t)=$ seasonal component, effect of seasonal factors action;

$c(t)=$ the cyclical component generated by the action of cyclic factors;

$u(t)=$ the residual component, which expresses the influence of the random factors on the evolution of the phenomenon.

A time series $y_{t}$ is stationary if:

$-E\left(y_{t}\right)=\bar{y}, \forall t=\overline{1, T}$

depend on time;

$-\operatorname{var}\left(y_{t}\right)=\sigma_{y}^{2}=$ constant,$\forall t=\overline{1, n}$

independent;

- $\operatorname{Cov}\left(y_{t}, y_{t+k}\right)=$ constant $, \forall t=\overline{1, n}, k<n$
(3) the average of the series does not

(4) the dispersion of the series is time

(5) the covariance of the series does not 
depend on time. (Stancu, S., 2011:381)

The definition above is the definition of weak stationarity. A series of time is therefore stationary if its media, dispersion and covariance remain constant over time. If any of the above conditions is not satisfied, then the time series is non-stationary.

If the first two conditions above can not be accepted, but $\operatorname{Cov}\left(y_{t}, y_{t+k}\right)=\rho(k), \forall t=$ $\overline{1, n}, k<n$ (3.10), where $\rho(k)$ represents the $k$-autocorrelation function, then the assumption of weak stationarity can be accepted.

The time series $\left\{\varepsilon_{t}\right\}_{t=\overline{1, T}}$ consisting of randomly uncorrelated variables, respectively: $-E\left(\varepsilon_{t}\right)=0, \forall t=\overline{1, T}$

$-\operatorname{var}\left(\varepsilon_{t}\right)=\sigma_{\varepsilon}^{2}, \forall t=\overline{1, n}$

$-\operatorname{Cov}\left(\varepsilon_{t}, \varepsilon_{p}\right)=0, \forall t, p=\overline{1, T}, t \neq p$

is called the white noise.

This series is stationary with the autocovariance function: $\rho(k)=\left\{\begin{array}{c}\sigma^{2}, k=0 \\ 0, \text { otherwise }\end{array}\right.$ and the autocorrelation function $r(k)=\left\{\begin{array}{c}1, k=0 \\ 0, \text { otherwise }\end{array}\right.$.

It is noted $W N\left(0, \sigma^{2}\right)$ the white noise, namely $\left\{\varepsilon_{t}\right\}_{t=\overline{1, T}} \approx W N\left(0, \sigma^{2}\right)$.

The time series $\left\{y_{t}\right\}_{t=\overline{1, T}}$, where $y_{t}=\varepsilon_{t}-\gamma \cdot \varepsilon_{t-1}, \gamma \neq 0$ and $\left\{\varepsilon_{t}\right\}_{t=\overline{1, T}} \approx W N\left(0, \sigma^{2}\right)$, is called the first-order moving average $M A(1)$, it is noted $\left\{y_{t}\right\}_{t=\overline{1, T}} \approx M A(1)$. This series is stationary for any $\gamma \neq 0$, has the mean 0 and the autocovariance function: $\rho(k)=$

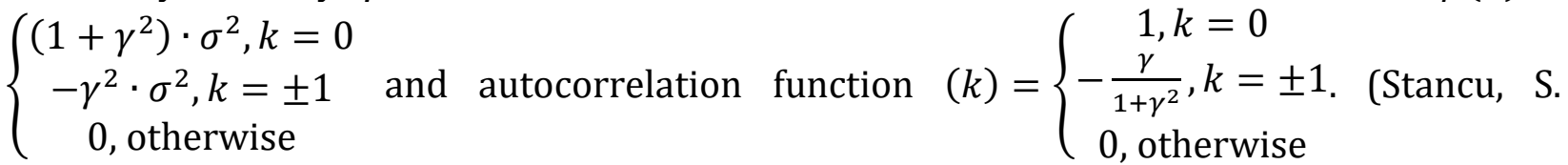
2011:399)

In analyzing time series, most of these are non-stationary.

A time series $\left\{y_{t}\right\}_{t=\overline{1, T}}$ is non-stationary if the mean and / or variance is variable over time. be:

Depending on the characteristics of the average, a non-stationary time series of may

- homogeneous non-stationary time series, in which case:

0 the average of the series is not constant over time, it has a linear trajectory with a positive or negative slope;

- the series is characterized by constant variations from one period to another.

- series of non-homogeneous non-stationary time, in which case:

$\circ$ both average and variance are variable over time;

- the series is characterized by non-constant variations from one period to another.

To test the stationarity of a time series, the following statistical tests are used:

- ADF test(Augmented Dickey-Fuller);

- PP test (Phillips-Perron).

The $t$ test(Student)

$H_{0}$ : the series has a unitary root (is non-stationary);

$t_{\text {test_ADF }}<t_{\text {critic }(1 \%, 5 \%, 10 \%)} \rightarrow$ is rejected $H_{0}$ (series is stationary)

Prob $<$ Relevance_Level $(1 \%, 5 \%, 10 \%) \rightarrow$ is rejected $H_{0}$ (series is stationary). (Stancu, S. 2011:416) 


\section{Implementation of statistical research methods for statistical analysis of investments in transport infrastructure, passenger numbers, and energy consumption by modes of transport in Romania}

In order to analyze the investments according to the number of passengers and the consumption of energy on national transport modes in Romania in a period of 15 years, respectively between 2000 and 2015. This will use the data published by the National Institute of Statistics, namely three indicators: investments in transport infrastructure, the weight of each mode in passenger transport and the consumption of energy by modes of transport.

The data series used are the following:

Table 1. Transport infrastructure investment

\begin{tabular}{|c|c|c|c|c|c|c|c|c|c|c|c|c|c|c|c|c|c|}
\hline \multicolumn{18}{|c|}{ Investitille în infrastructura de transport } \\
\hline \multicolumn{18}{|c|}{ (Transport infrastructure investment) } \\
\hline Simbol: & IT & & & & & & & & & & & & & & & & \\
\hline U.M.: & milioane lei ( & & & & & & & & & & & & & & & & \\
\hline \multirow[t]{2}{*}{ Nivel de agregare: } & național, tipu & i de lucre & & & & & & & & & & & & & & & \\
\hline & 2000 & 2001 & 2002 & 2003 & 2004 & 2005 & 2006 & 2007 & 2008 & 2009 & 2010 & 2011 & 2012 & 2013 & 2014 & 2015 & $2016^{*}$ \\
\hline Total & 1679.7 & 2710.2 & 2884.7 & 3849 & 5712.2 & 6002.9 & 8229.8 & 12088.2 & 20418.5 & 19541.9 & 17687.0 & 19613.2 & 19375.2 & 17649.8 & 16145.5 & $\begin{array}{c}19963.3 \\
\end{array}$ & 15623.5 \\
\hline Şosele, străzi şi drumuri & 1256.8 & 1913.1 & 1982.4 & 2655.9 & $\begin{array}{l}4437.4 \\
\end{array}$ & 4821.7 & 6875.3 & 9358.6 & 14330.1 & 13165.1 & 12005.4 & 13917.9 & 13788.2 & 12058.7 & \begin{tabular}{ll|l}
11077.7 \\
\end{tabular} & $\begin{array}{l}12759.3 \\
\end{array}$ & 10628.8 \\
\hline Că ferate & 85.6 & 148.4 & 332.2 & 370.6 & 234.1 & 395.3 & 358.8 & 1037.2 & $\begin{array}{c}1165.3 \\
\end{array}$ & 752.1 & 711.3 & 684.3 & 524.8 & 923.1 & 1233.6 & 1431.4 & 1177.1 \\
\hline Piste pentru aeroporturi & 13.5 & 18.7 & 44.1 & 9.6 & 9.4 & 7.0 & 53.3 & 139.6 & 33.6 & 26.0 & 3.7 & 9.0 & 93.9 & 85.4 & \begin{tabular}{c|c|}
126.6 \\
\end{tabular} & $\begin{array}{l}172.2 \\
\end{array}$ & 100.4 \\
\hline $\begin{array}{l}\text { Poduri, sosele suspendate, tunele } \\
\text { ş subterane }\end{array}$ & 114.4 & 191.1 & 201.6 & 198.4 & 259.0 & 273.0 & 191.9 & 356.2 & 3084.9 & 3325.3 & 3184.0 & 2801.7 & 3722.7 & 3398.0 & 2311.9 & 3351.5 & 2652.8 \\
\hline $\begin{array}{l}\text { Canale navigabile, construcţii } \\
\text { portuare şi alte construcţii } \\
\text { hidrotehnice }\end{array}$ & 9.4 & 439 & 24.5 & 614.6 & 72.4 & 505.9 & 750.5 & 1196.6 & 1804.6| & 2273.4 & $32.6 \mid$ & 2200.3 & 45.6 & 1184.6 & 1395.7 & 88.9| & 1064. \\
\hline
\end{tabular}

* date provizorii

Source: National Institute of Statistics

Table 2. Passengers transported in interurban and international passenger transport on modes of transport

Rezultatele cautarii - Pasageri transportati in transportul interurban si international de pasageri, pe moduri de transport

\begin{tabular}{|c|c|c|c|c|c|c|c|c|c|c|c|c|c|c|c|c|c|c|}
\hline \multirow{4}{*}{ Moduri de transport } & \multicolumn{18}{|c|}{ Ani } \\
\hline & Anul 2000 & Anul 2001 & Anul 2002 & Anul 2003 & Anul 2004 & Anul 2005 & Anul 2006 & Anul 2007 & Anul 2008 & Anul 2009 & Anul 2010 & Anul 2011 & Anul 2012 & Anul 2013 & Anul 2014 & Anul 2015 & Anul 2016 & Anul 2017 \\
\hline & \multicolumn{18}{|c|}{ UM: Mii pasageri } \\
\hline & lii pasageri & Mii pasageri & Mii pasager & Mii pasager & Mii pasager & Mii pasage & Mii pasageri & Mii pasageri & Mii pasageri & Mii pasageri I & Mii pasageri & Mii pasageri & Mii pasageri & Mii pasageri $\mathrm{N}$ & Mii pasageri & Mii pasageri & Mii pasageri & Mii pasageri \\
\hline Transport feroviar & 117501 & 113718 & 95618 & 94810 & 99434 & 92424 & 94441 & 88264 & 78252 & 70332 & 64272 & 61001 & 57562 & 57433 & 64760 & 66482 & 64456 & 69057 \\
\hline Transport rutier & 205979 & 200093 & 191127 & 216327 & 216524 & 238017 & 228009 & 231077 & 296953 & 262311 & 244944 & 242516 & 262291 & 274393 & 282018 & 275548 & 302951 & 325532 \\
\hline Transport aerian & 2358 & 2503 & 2579 & 2900 & 3406 & 4339 & 5497 & 7831 & 9077 & 9093 & 10128 & 10783 & 10728 & 10706 & 11592 & 13273 & 16398 & 20222 \\
\hline
\end{tabular}

Legenda: ':' - date lipsa; 'c' - date confidentiale; 9999,00 - normal - date definitive; 9999,00 - ingrosat subliniat - date semidefinitive; 9999,00 - ingrosat - date revizuite; 9999,00 - subliniat - date provizorii

(c) 1998 - 2018 INSTITUTUL NATIONAL DE STATISTICA

Source: National Institute of Statistics

Table 3. Energy consumption by transport mode

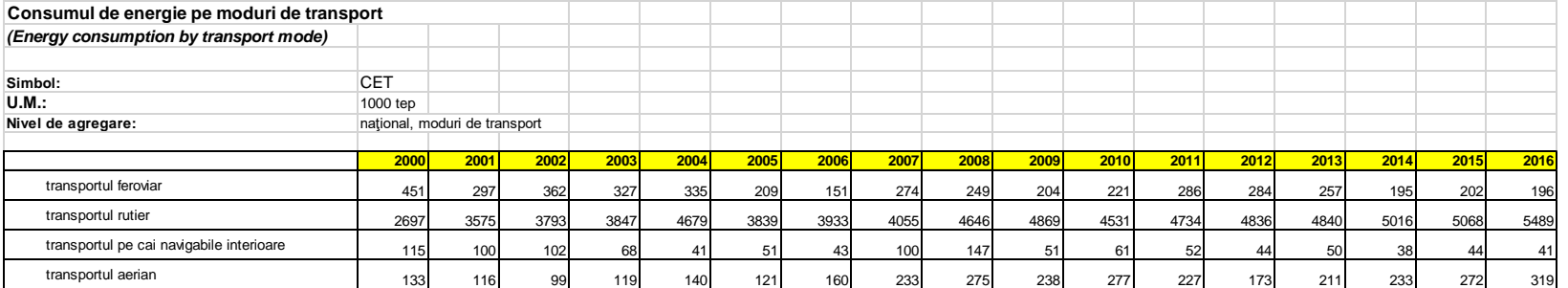

Source: National Institute of Statistics 
To build the multifactor regression model, we used the following variables:

- Endogenous variables, namely "Investment in transport infrastructure":

CAI_FERATE

PODURI_SOSELE_SUSPENDAT

PISTE_PENTRU_AEROPORTURI,

SOSELE_STRAZI_SI_DRUMUR

- Exogenous variables, namely "Passengers transported in interurban and international passenger transport by modes of transport":

TRANSPORT_FEROVIAR

TRANSPORT_RUTIER

TRANSPORT_AERIAN

- and "Energy consumption by modes of transport":

E_T_FEROVIAR

E_T_RUTIER

E_T_AERIAN

To determine the regression equations we used the EViews program package as follows:

1. For the railways we have obtained:

Table 4. Estimated model of the variable CAI_FERATE

Dependent Variable: CAI_FERATE

Method: Least Squares

Sample (adjusted): 20002016

Included observations: 17 after adjustments

\begin{tabular}{lrrrr}
\hline \hline & & & & \\
\multicolumn{1}{c}{ Variable } & Coefficient & Std. Error & t-Statistic & Prob. \\
& & & & \\
\hline \hline & & & & \\
$\quad$ E_T_FEROVIAR & -1.477134 & 1.186217 & -1.245248 & 0.2335 \\
TRANSPORT_FEROVIAR & -0.012168 & 0.004542 & -2.678799 & 0.0180 \\
\multicolumn{1}{c}{ C } & 2059.646 & 331.4597 & 6.213865 & 0.0000 \\
& & & & \\
\hline \hline & & & \\
R-squared & 0.565155 & Mean dependent var & 680.3059 \\
Adjusted R-squared & 0.503034 & S.D. dependent var & 418.8022 \\
S.E. of regression & 295.2380 & Akaike info criterion & 14.37223 \\
Sum squared resid & 1220316. & Schwarz criterion & 14.51926 \\
Log likelihood & -119.1639 & Hannan-Quinn criter. & 14.38684 \\
F-statistic & 9.097685 & Durbin-Watson stat & 1.173366 \\
Prob(F-statistic) & 0.002940 & & \\
& & & \\
\hline \hline
\end{tabular}

Source: Processed data using the program EViews

2. For air transport, we obtained: 
Table 5. Estimated model of the variable PISTE_PENTRU_AEROPORTURI

Dependent Variable: PISTE_PENTRU_AEROPORTURI

Method: Least Squares

Sample (adjusted): 20002016

Included observations: 17 after adjustments

\begin{tabular}{lrlll}
\hline \hline \multicolumn{1}{c}{ Variable } & Coefficient & Std. Error & t-Statistic & Prob. \\
\hline \hline TRANSPORT_AERIAN & 0.012034 & 0.005843 & 2.059654 & 0.0585 \\
$\quad$ E_T_AERIAN & -0.313354 & 0.366881 & -0.854103 & 0.4074 \\
\multicolumn{1}{c}{ C } & 23.04256 & 38.62263 & 0.596608 & 0.5603 \\
\hline \hline R-squared & 0.400128 & Mean dependent var & 55.64706 \\
Adjusted R-squared & 0.314432 & S.D. dependent var & 53.71440 \\
S.E. of regression & 44.47502 & Akaike info criterion & 10.58652 \\
Sum squared resid & 27692.38 & Schwarz criterion & 10.73356 \\
Log likelihood & -86.98540 & Hannan-Quinn criter. & 10.60113 \\
F-statistic & 4.669148 & Durbin-Watson stat & 1.433434 \\
Prob(F-statistic) & 0.027952 & & \\
\hline
\end{tabular}

Source: Processed data using the program EViews

3. For road transport, we obtained:

Table 6. Estimated model of the variable SOSELE_STRAZI_SI_DRUMUR

Dependent Variable: SOSELE_STRAZI_SI_DRUMUR

Method: Least Squares

Sample (adjusted): 20002016

Included observations: 17 after adjustments

\begin{tabular}{lrlrr}
\hline \hline & & & & \\
\multicolumn{1}{c}{ Variable } & Coefficient & Std. Error & t-Statistic & Prob. \\
& & & & \\
\hline \hline & & & & \\
TRANSPORT_RUTIER & 0.075201 & 0.033899 & 2.218355 & 0.0436 \\
$\quad$ E_T_RUTIER & 2.540939 & 1.649875 & 1.540080 & 0.1458 \\
\multicolumn{1}{c}{ C } & -20929.49 & 4913.942 & -4.259206 & 0.0008 \\
& & & & \\
\hline \hline & & & \\
R-squared & 0.729754 & Mean dependent var & 8648.965 \\
Adjusted R-squared & 0.691148 & S.D. dependent var & 4827.396 \\
S.E. of regression & 2682.800 & Akaike info criterion & 18.78590 \\
Sum squared resid & $1.01 \mathrm{E}+08$ & Schwarz criterion & 18.93293 \\
Log likelihood & -156.6801 & Hannan-Quinn criter. & 18.80051 \\
F-statistic & 18.90235 & Durbin-Watson stat & 0.667935 \\
Prob(F-statistic) & 0.000105 & & \\
& & & \\
\hline \hline
\end{tabular}

Source: Processed data using the program EViews

Report of determination $R^{2}$ shows the proportion of variation of the dependent 
variable explained by the regression model and is used to evaluate the quality of the adjustment (choice of model). In our case, for railways, $R^{2}=0,565155$, then the chosen regression model explains the link between the variables; for air transport, $R^{2}=0,400128$, then the chosen regression model does not explain the link between the variables and the road transport, $R^{2}=0,729754$, then the chosen regression model explains the link between the variables.

The residues of the estimated regression model respect the hypothesis of normality, lack of autocorrelation, homoscedasticity, and do not differ statistically significantly from 0 .

The significance of each regression coefficient is given by the Wald test. In our case, the significant level of this test (column Prob.) is less than 0.05 as follows: for railways, TRANSPORT_FEROVIAR variable, for air transport, no variable, and TRANSPORT_RUTIER for road transport, so the parameters can be kept in model only in the two mentioned situations.

Therefore, the estimated model becomes:

- for railways, CAI_FERATE $=-0.012168 *$ TRANSPORT_FEROVIAR $+\mathrm{c}$,

- for road transport, SOSELE_STRAZI_SI_DRUMUR $=0.075201 *$ TRANSPORT_RUTIER $+\mathrm{c}$.

In order to analyze the evolution of investments, passenger numbers and energy consumption in national transport modes in Romania over a period of 15 years, we have completed the following stages:

- For railways, the time series has the following chart:

\section{Cai ferate}

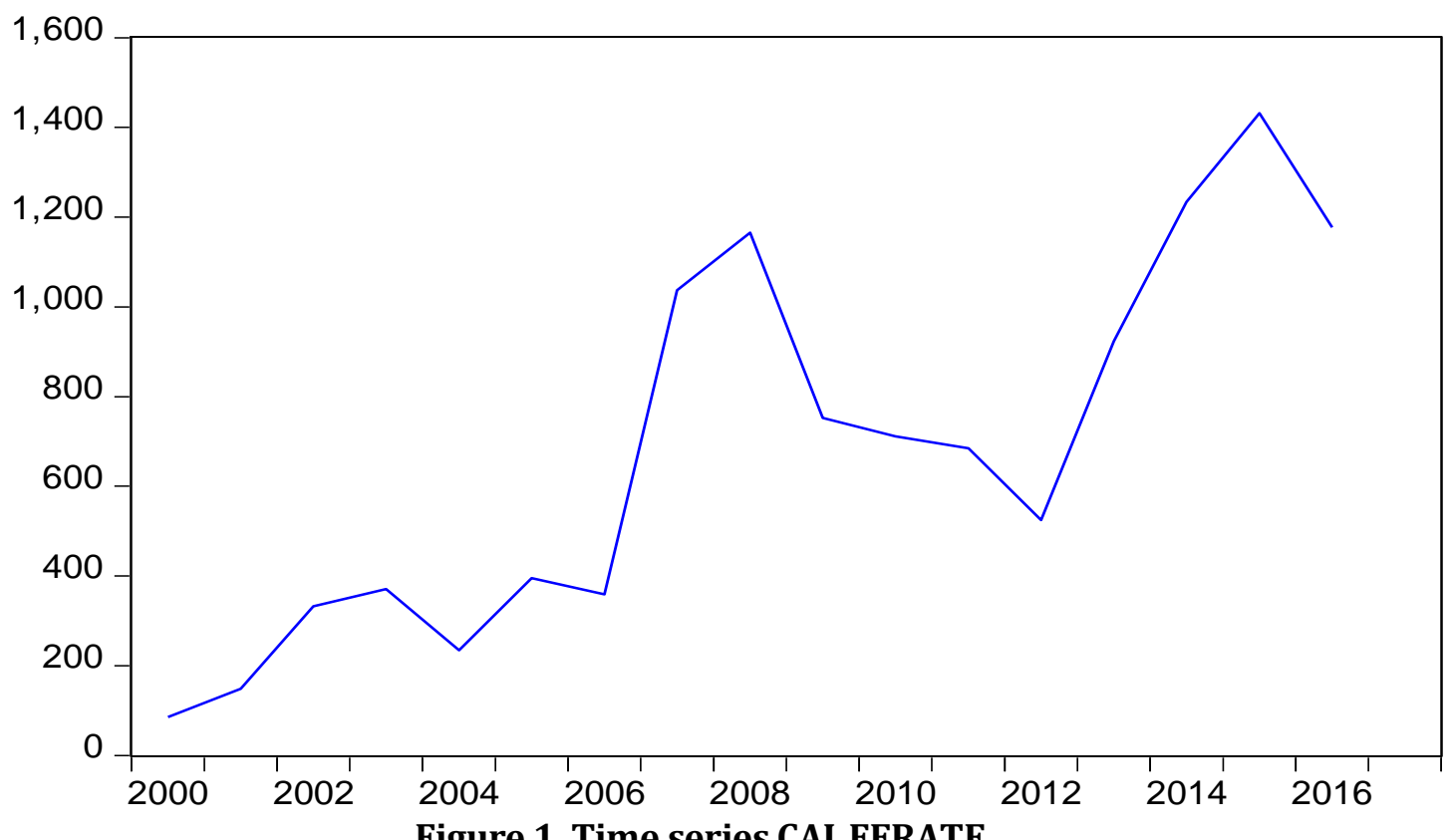

Source: Processed data using the program EViews

The results of the Augmented Dickey-Fuller ADF test for the time series presented are as follows: 
Table 7. The Augmented Dickey-Fuller ADF test for the time series CAI_FERATE

Null Hypothesis: CAI_FERATE has a unit root

Exogenous: Constant

Lag Length: 0 (Automatic - based on SIC, maxlag=3)

\begin{tabular}{lccc}
\hline \hline & & & \\
& & t-Statistic & Prob.* \\
\hline \hline & & & \\
Augmented Dickey-Fuller test statistic & -1.421912 & 0.5454 \\
\hline Test critical values: $\quad$ 1\% level & -3.920350 & \\
& 5\% level & -3.065585 & \\
& $10 \%$ level & -2.673459 & \\
& & & \\
\hline \hline
\end{tabular}

*MacKinnon (1996) one-sided p-values.

Warning: Probabilities and critical values calculated for 20 observations and may not be accurate for a sample size of 16

Augmented Dickey-Fuller Test Equation

Dependent Variable: D(CAI_FERATE)

Method: Least Squares

Date: 05/20/19 Time: 22:35

Sample (adjusted): 20012016

Included observations: 16 after adjustments

\begin{tabular}{lrlrr}
\hline \hline \multicolumn{1}{c}{ Variable } & Coefficient & Std. Error & t-Statistic & Prob. \\
& & & & \\
\hline \hline & & & & \\
\multicolumn{1}{c}{ CAI_FERATE(-1) } & -0.227643 & 0.160096 & -1.421912 & 0.1769 \\
\multicolumn{1}{c}{ C } & 216.0174 & 121.9825 & 1.770889 & 0.0983 \\
& & & & \\
\hline \hline & & & \\
R-squared & 0.126192 & Mean dependent var & 68.21875 \\
Adjusted R-squared & 0.063778 & S.D. dependent var & 263.9117 \\
S.E. of regression & 255.3572 & Akaike info criterion & 14.03967 \\
Sum squared resid & 912902.4 & Schwarz criterion & 14.13625 \\
Log likelihood & -110.3174 & Hannan-Quinn criter. & 14.04462 \\
F-statistic & 2.021835 & Durbin-Watson stat & 1.761489 \\
Prob(F-statistic) & 0.176946 & & \\
& & & \\
\hline
\end{tabular}

Source: Processed data using the program EViews

As you can see $t_{\text {test } A D F}=-1.421912$ and the associated $p$ value is 0.5454 . Because $t_{\text {test_ADF }}<t_{\text {critic }(1 \%, 5 \%, 10 \%)}$ we accept $H_{0}$, so the series is non-stationary.

First order differences are calculated, then the ADF test is performed. The results of the Augmented Dickey-Fuller ADF test for the time series are as follows: 
Table 8. The Augmented Dickey-Fuller ADF test for the time series D_CAI_FERATE

Null Hypothesis: D_CAI_FERATE has a unit root

Exogenous: Constant

Lag Length: 0 (Automatic - based on SIC, maxlag=3)

\begin{tabular}{lccc}
\hline \hline & & & \\
& & t-Statistic & Prob.* \\
\hline \hline & & & \\
Augmented Dickey-Fuller test statistic & -3.423721 & 0.0269 \\
\hline Test critical values: $\quad$ 1\% level & -3.959148 & \\
& 5\% level & -3.081002 & \\
& $10 \%$ level & -2.681330 & \\
& & & \\
\hline \hline
\end{tabular}

*MacKinnon (1996) one-sided p-values.

Warning: Probabilities and critical values calculated for 20 observations and may not be accurate for a sample size of 15

Augmented Dickey-Fuller Test Equation

Dependent Variable: D(D_CAI_FERATE)

Method: Least Squares

Date: 05/20/19 Time: 22:43

Sample (adjusted): 20022016

Included observations: 15 after adjustments

\begin{tabular}{lrlrr}
\hline \hline \multicolumn{1}{c}{ Variable } & Coefficient & Std. Error & t-Statistic & Prob. \\
& & & & \\
\hline \hline & & & & \\
\multicolumn{1}{c}{ D_CAI_FERATE(-1) } & -1.004377 & 0.293358 & -3.423721 & 0.0045 \\
\multicolumn{1}{c}{ C } & 68.97266 & 77.78265 & 0.886736 & 0.3913 \\
& & & & \\
\hline \hline & & & & \\
R-squared & 0.474150 & Mean dependent var & -21.14000 \\
Adjusted R-squared & 0.433700 & S.D. dependent var & 376.7029 \\
S.E. of regression & 283.4800 & Akaike info criterion & 14.25573 \\
Sum squared resid & 1044692. & Schwarz criterion & 14.35013 \\
Log likelihood & -104.9179 & Hannan-Quinn criter. & 14.25472 \\
F-statistic & 11.72186 & Durbin-Watson stat & 1.889087 \\
Prob(F-statistic) & 0.004531 & & \\
& & & \\
\hline
\end{tabular}

Source: Processed data using the program EViews

As you can see $t_{\text {test_ADF }}=-3.423721$ and the associated $p$ value is 0.0269 . Because $t_{\text {test_ADF }}<t_{\text {critic }(1 \%, 5 \%, 10 \%)}$ we accept $H_{0}$, so the series is non-stationary.

We calculate the second order differences, then perform the ADF test. The results of the Augmented Dickey-Fuller ADF test for the time series are as follows: 
Table 9. The Augmented Dickey-Fuller ADF test for the time series D2_CAI_FERATE Null Hypothesis: D2_CAI_FERATE has a unit root Exogenous: Constant Lag Length: 0 (Automatic - based on SIC, maxlag=3)

\begin{tabular}{lccc}
\hline \hline & & & \\
& & t-Statistic & Prob.* \\
\hline \hline & & & \\
\multicolumn{2}{l}{ Augmented Dickey-Fuller test statistic } & -4.646950 & 0.0032 \\
\hline Test critical values: $\quad$ 1\% level & -4.004425 & \\
& 5\% level & -3.098896 & \\
& 10\% level & -2.690439 & \\
& & & \\
\hline \hline
\end{tabular}

*MacKinnon (1996) one-sided p-values.

Warning: Probabilities and critical values calculated for 20 observations and may not be accurate for a sample size of 14

Augmented Dickey-Fuller Test Equation Dependent Variable: D(D2_CAI_FERATE)

Method: Least Squares

Date: 05/20/19 Time: 22:48

Sample (adjusted): 20032016

Included observations: 14 after adjustments

\begin{tabular}{lrllr}
\hline \hline \multicolumn{1}{c}{ Variable } & Coefficient & Std. Error & t-Statistic & Prob. \\
& & & & \\
\hline \hline & & & & \\
D2_CAI_FERATE(-1) & -1.333413 & 0.286944 & -4.646950 & 0.0006 \\
& -28.07780 & 102.5736 & -0.273733 & 0.7889 \\
& & & & \\
\hline \hline & & & & \\
R-squared & 0.642795 & Mean dependent var & -40.93571 \\
Adjusted R-squared & 0.613028 & S.D. dependent var & 616.7391 \\
S.E. of regression & 383.6554 & Akaike info criterion & 14.86893 \\
Sum squared resid & 1766298. & Schwarz criterion & 14.96022 \\
Log likelihood & -102.0825 & Hannan-Quinn criter. & 14.86048 \\
F-statistic & 21.59415 & Durbin-Watson stat & 2.078578 \\
Prob(F-statistic) & 0.000563 & & \\
& & & \\
\hline
\end{tabular}

Source: Processed data using the program EViews

As you can see $t_{\text {test } A D F}=-4.646950$ and the associated $p$ value is 0.0032 . Because $t_{\text {test_ADF }}>t_{\text {critic }(1 \%, 5 \%, 10 \%)}$ we reject $H_{0}$, so the series is stationary.

The error log is used to choose the ARMA model specification. To be able to analyze autocorrelation coefficients and partial autocorrelation coefficients, select View $\rightarrow$ Correlogram, available in the window of the considered series.

The corelogram obtained for the D2_CAI_FERATE variable is as follows: 
Sample: 20002017

Table 10. The corelogram for the time series D2_CAI_FERATE

Included observations: 15

\begin{tabular}{|c|c|c|c|c|c|c|}
\hline Autocorrelation & Partial Correlation & & $\mathrm{AC}$ & PAC & Q-Stat & Prob \\
\hline${ }^{* *} \cdot \mid$ & $*^{* *} \cdot \mid$ & 1 & -0.302 & -0.302 & 1.6636 & 0.197 \\
\hline & $*^{* * 1} \cdot \mid$ & 2 & -0.179 & -0.298 & 2.2933 & 0.318 \\
\hline$\left.\right|^{*}$ & $\cdot * 1 \cdot 1$ & 3 & 0.097 & -0.076 & 2.4928 & 0.477 \\
\hline$*^{* * 1} \cdot 1$ & $* *|\cdot|$ & 4 & -0.236 & -0.337 & 3.7818 & 0.436 \\
\hline & $* *|\cdot|$ & 5 & -0.018 & -0.301 & 3.7898 & 0.580 \\
\hline . $\left.\right|^{*}$ & $*^{*} \cdot 1$ & 6 & 0.151 & -0.179 & 4.4321 & 0.618 \\
\hline .1 &.$* 1.1$ & 7 & -0.021 & -0.171 & 4.4466 & 0.727 \\
\hline $.1^{* *} . \mid$ & $.1^{*} .1$ & 8 & 0.214 & 0.141 & 6.1195 & 0.634 \\
\hline$*^{*} \cdot 1$ & $\cdot * 1.1$ & 9 & -0.198 & -0.131 & 7.7784 & 0.557 \\
\hline$\cdot 1 \cdot 1$ & .1 .1 & 10 & -0.015 & 0.007 & 7.7906 & 0.649 \\
\hline 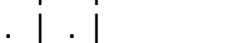 & $*|\cdot|$ & 11 & -0.016 & -0.097 & 7.8079 & 0.730 \\
\hline | & $\left.\cdot\right|^{*} .1$ & 12 & 0.034 & 0.118 & 7.9080 & 0.792 \\
\hline
\end{tabular}

Source: Processed data using the program EViews

According to the time series correlation, it can be seen that the autocorrelation function (AC) has the first 3 significant values different from 0 and decreasing. Also, the first three values of the partial autocorrelation function (ACP) differ significantly from 0 . It can be concluded that the series will comprise a MA component with the number of lags (q) equal to at most 3, and that the autoregressive process has an AR component of order $\mathrm{p}=3$.

An equation could be: D2_CAI_FERATE ar (1) ar (2) ar (3) ma (1) ma (2) ma (3) c. The results of estimating the parameters generated with EViews are as follows:

\section{Table 11. The estimated equation for the time series D2_CAI_FERATE}

Dependent Variable: D2_CAI_FERATE

Method: ARMA Conditional Least Squares (Gauss-Newton / Marquardt

steps)

Sample (adjusted): 20052016

Included observations: 12 after adjustments

Failure to improve likelihood (non-zero gradients) after 173 iterations

Coefficient covariance computed using outer product of gradients

MA Backcast: OFF (Roots of MA process too large)

\begin{tabular}{crrrr}
\hline \hline Variable & Coefficient & Std. Error & t-Statistic & Prob. \\
\hline \hline C & & & & \\
AR(1) & 23.58175 & 42.09142 & 0.560251 & 0.5995 \\
AR(2) & -1.120249 & 0.543829 & -2.059930 & 0.0944 \\
AR(3) & -0.650998 & 0.784014 & -0.830339 & 0.4442 \\
MA(1) & -0.487807 & 0.588796 & -0.828482 & 0.4451 \\
MA(2) & -1.711857 & 2.207691 & -0.775406 & 0.4732 \\
MA(3) & -3.671649 & 2.440810 & -1.504275 & 0.1928 \\
\hline \hline
\end{tabular}




\begin{tabular}{|c|c|c|c|}
\hline R-squared & 0.929661 & Mean dependent var & -9.816667 \\
\hline Adjusted R-squared & 0.845253 & S.D. dependent var & 418.4219 \\
\hline S.E. of regression & 164.5982 & Akaike info criterion & 13.33609 \\
\hline Sum squared resid & 135462.8 & Schwarz criterion & 13.61895 \\
\hline Log likelihood & -73.01654 & Hannan-Quinn criter. & 13.23136 \\
\hline F-statistic & 11.01399 & Durbin-Watson stat & 2.351201 \\
\hline Prob(F-statistic) & 0.009324 & & \\
\hline Inverted AR Roots & $-.08+.71 \mathrm{i}$ & $-.08-.71 \mathrm{i}$ & \\
\hline Inverted MA Roots & 3.02 & -.29 & \\
\hline
\end{tabular}

Source: Processed data using the program EViews

As it can be seen we can say that the autoregressive model is valid because F-statistic $=11.01399>\mathrm{F}$ critical and Prob (F-statistic) $=0.009324<0.05$. Since the value of the DurbinWatson test is 2.351201 and is close to 2 then it can be said that there is no serial correlation between the residues.

The equation thus obtained for the variable CAI_FERATE is:

CAI_FERATE $=23.58175-1.120249 *$ CAI_FERATE ${ }_{t-1}-0.650998 *$ CAI_FERATE $_{t-2}{ }^{-}$ $0.487807^{*}$ CAI_FERATE ${ }_{t-3}-1.711857^{*} \varepsilon_{t}-3.671649^{*} \varepsilon_{t-1}-0.891095^{*} \varepsilon_{t-2}$.

\section{Conclusions}

In order to analyze the investments according to the number of passengers and the consumption of energy on national transport modes in Romania in a period of 15 years, respectively between 2000 and 2015. This will use the data published by the National Institute of Statistics, namely three indicators: investments in transport infrastructure, the weight of each mode in passenger transport and the consumption of energy by modes of transport.

The estimated regression model is as follows:

- for railways, CAI_FERATE $=-0.012168 *$ TRANSPORT_FEROVIAR $+\mathrm{c}$,

- for road transport, SOSELE_STRAZI_SI_DRUMUR $=0.075201 *$ TRANSPORT_RUTIER $+\mathrm{c}$.

According to the time series correlation, it can be seen that the autocorrelation function (AC) has the first 3 significant values different from 0 and decreasing. Also, the first three values of the partial autocorrelation function (ACP) differ significantly from 0 . It can be concluded that the series will comprise a MA component with the number of lags (q) equal to at most 3 , and that the autoregressive process has an AR component of order $\mathrm{p}=3$.

The equation thus obtained for CAI_FERATE is:

CAI_FERATE $=23.58175-1.120249 *{ }^{*}$ CAI_FERATE $_{t-1}-0.650998 *$ CAI_FERATE $_{t-2}{ }^{-}$ $0.487807 *$ CAI_FERATE ${ }_{t-3}-1.711857^{*} \varepsilon_{t}-3.671649 * \varepsilon_{t-1}-0.891095^{*} \varepsilon_{t-2}$.

\section{References}

Isaic-Maniu, A., Mitrut, C., Voineagu, V. (1999). Statistica pentru managementul afacerilor, Editura Economică, București

Voineagu, V., Boboc, C., Ghita, S., Titan, E. (2007). Statistica : baze teoretice si aplicatii, Editura Economică, București

Tudorel, A., Regis, B. (2008). Econometrie, Editura Economică, Bucuresti

Stancu, S., (2011). Econometrie. Teorie si aplicatii utilizând EViews, Editura ASE, Bucuresti

Tudorel, A., Stancu, S., Iacob, A. I., Tușa, E., (2008). Introducere în econometrie utilizând Eviews, Editura Economică, București 